\title{
Drosophila Protein
}

National Cancer Institute

\section{Source}

National Cancer Institute. Drosophila Protein. NCI Thesaurus. Code C20159.

Proteins found in Drosophila. 